\title{
MULTIDIMENSIONAL POVERTY ANALYSIS OF URBAN AND RURAL HOUSEHOLDS IN SOUTH AFRICA
}

\author{
Ebenezer Toyin MEGBOWON* \\ University of Fort Hare, South Africa
}

\begin{abstract}
The study profiled and compared household multidimensional poverty status and its determinants among urban and rural households in the Eastern Cape Province of South Africa, using information from a sample population of 3033 households interviewed from the Province during the General Household Survey conducted by the Statistics South Africa in 2014. Analytical techniques utilized include the recent multidimensional poverty index (MPI), descriptive statistics and Tobit regression. Findings reveal that multiple deprivations are found mostly in the rural area of the province; the multidimensional headcount is highest in the rural area, though the intensity of multidimensional poverty is almost similar in both geographical locations. The standard of living dimension is also the largest contribution to MPI in both locations. MPI has significant links with education attainment of household head, access to electricity and asset stock in both geographical locations, but is influenced by the gender of head, agriculture engagement and household monthly income in rural areas only. In order to improve households' multidimensional poverty status in both urban and rural locations, there is the need to take into account some significant variables such as education of head, increase electricity subsidy coverage during winter period, asset accumulation and increase in households' participation in agricultural activities, especially those residing in rural areas.
\end{abstract}

JEL classification: 132

Keywords: Multidimensional Poverty Index, Urban, Rural, Tobit Regression

\section{Introduction and Background}

Poverty is a composite phenomenon which has been examined by many scholars and development associates in diverse ways. Though there have been various versions of definitions of the term poverty (World Bank, 1990; Lipton et al., 1995; United Nations, 1998; World Bank, 2001; Chamhuri et al., 2004; Abdul-Mamin and Shamshiry, 2014) over

\footnotetext{
* Corresponding author. Address: Department of Agricultural Economics and Extension, University of
} Fort Hare, South Africa, Phone: +27745174250, E-mail: megbowontoyin@gmail.com 
the decades, there is, however, no specific generally accepted definition of poverty due to its multifacetedness. Following the definition given by Abdul-Mamin and Shamshiry (2014), poverty is defined as a diversity of deprivations a person or household experiences simultaneously or separately that stifles the person's or households' abilities to function, live a life of purpose and fulfilment, and be productive in the society. These deprivations could be economic, social, political, cultural, physical or spiritual. From this definition and various perspectives, poverty is viewed as the existence of poverty that is generally accepted as a phenomenon which goes beyond income and consumption standard but includes a state of wellbeing, which is economically, morally and socially unacceptable, caused by various dynamic interactions which make some better-off and others worse off. Hence, since poverty goes beyond income and consumption, targeting and ending it in all forms becomes appropriate. To this end, ending all forms of poverty by 2030 became a goal generally agreed on by world leaders during the United Nations Sustainable Development Summit in September 2015 as one of the Sustainable Development Goal (SDG) to be achieved.

South Africa and the Eastern Cape Province in particular have made significant progress in poverty reduction since the official end of the Apartheid government in 1994. However, despite this improvement, various studies that have been carried out still report existence of poverty among households in the country. The latest report by Stats SA (2017), where different poverty lines (upper bound poverty line, lower bound poverty line, food poverty) were used, revealed that there was a slight increase in poverty situation in the country between 2001 and 2015. For instance, in 2015 the UBPL indicates that 30.4 million South Africans live in poverty in 2015, which was an increase to $55.8 \%$ poor people from $53.2 \%$ in 2011 . The Eastern Cape Province remained consistently ranked in the top most position of either first or second poverty stricken provinces in South Africa. Nevertheless, the provincial government is striving and committed to improving the welfare of its people and also achieve the Sustainable Development Goal of ending all forms of poverty, it has been achieving this through social wage and protection programmes. This is why the Eastern Cape Province is home to 2770521 people receiving social grants, the second largest after the KwaZulu-Natal Province. However, the pursuit of ending all forms of poverty by the year 2030, as indicated in the SDG and the South African NDP, cannot be achieved when the multidimensional nature of poverty in measurement and the peculiarities of geographical locations within an economy are not taken into consideration. Aside, it is well known that national level analysis does not provide a clear picture of poverty situation at the subnational level, bearing the peculiarities of geographical location in the country in mind. Considering the geographical effect of the Apartheid system of government in South Africa, it is known that the extent of effects differs across provinces and localities. As noted by Mushongera et al. (2017), racial and location imbalances persist till to date, despite government efforts in the past 20 years. These imbalances are further seen in the differences in geographical space development, and in prices of goods and services as well. Hence, the appraisal of poverty dynamics focusing at sub-national and localized level becomes appropriate. Hence, this paper assesses the multidimensional nature of poverty among urban and rural households in the Eastern Cape Province, using the most recent multidimensional poverty measure (Alkire and Foster, 2011) Multidimensional Poverty Index. Specifically, the objective of the paper is to profile and compare household multidimensional poverty status, and investigate factors influencing household multidimensional poverty among both urban and rural households in the Eastern Cape Province of South Africa. 
The rest of the article is arranged as follows, section 2 provides the literature review while section 3 and 4 present the data source and analytical techniques respectively. The analytical techniques include the discussion on MPI and the Tobit regression model adopted in the study. Section 5 presents results and discussion, while conclusions and recommendations follow in Section 6. The global pursuit of reducing every form of poverty underscores the importance and relevance of this study for other regions outside Africa. Moreover, the utilization of Alkire and Foster (2011) MPI used in this study, if applied to other poverty stricken regions, could help specifically identify channels through which multidimensional poverty manifest itself in those regions. Furthermore, in trying to analyse multidimensional poverty in both urban and rural household, the study portrays the existence of non-homogeneity within an economy which is indispensable in understanding multidimensional poverty in other regions.

\section{Literature Review}

In South Africa, there is an abundance of empirical literature on poverty the same way it is available in global community. The majority of this research has examined poverty from a unidimensional perspective, using solely the monetary or non-monetary subjective concepts. The multidimensional nature of poverty poses several arguments among scholars against these unidimensional measures in terms of how best poverty can be better captured beyond the unidimensional measures. For instance, monetary measurement of poverty using expenditure or income has been used as main indicators in establishing poverty thresholds by these studies (Biyase and Zwane, 2018; Dunga, 2017; Maloma, 2016; Meyer and Nishimwe, 2016; Wurku and Marangu, 2015; Baiyegunhi and Fraser, 2014; Baiyegunhi, 2014; Sekhampu, 2013). Though monetary measure captures welfare (i.e. welfare opportunity and welfare realized), it is, however, argued that the approach is inadequate as it captures only a unidimensional approach of poverty. It is also argued that monetary poverty measures often ignore the non-income components of living standards (Meth and Dias 2004; Seekings 2007) like including in-kind benefits, free or subsidized primary healthcare, education, and sanitation, hence this measure, if not correlated with several other dimensions of the household's living standards, could misrepresent the extent of household. Moreover, current income can be a misleading indicator of economic status of family because earnings are susceptible to fluctuations due to transitory events (Meyer and Sullivan, 2003) and the difficulties in collecting appropriate data on income and expenditure (Posel and Rogan, 2014). Similarly, the use of non-monetary one-dimensional approach of subjective measure has also been argued against in literature. Gibson (2016) argued that welfare economics does not provide a justification for maximizing either happiness or life satisfaction, because neither corresponds to utility. Accordingly, Jansen et al. (2015) argued that subjective indicators might be less expedient for practical policy and targeting purposes as people may project themselves as poor only because they are not satisfied with their lives, which is challenging for instance, when targeting the public for welfare programmes. Subjective measure could also present false information because the relative position of household is a strong determinant of subjective poverty, as pointed out by Alem et al. (2014). For example, having some kind of employment makes a household less likely to perceive themselves as poor, even if they remain in objective poverty. 
There is a gradual increase in the number of studies adopting non-monetary multidimensional approaches to poverty measure in South Africa recently. These studies have applied asset-based approaches to measure poverty based on a household's access to public and private assets (Bhorat, van der et al., 2009). Other studies have also used composite indices approach to develop national and provincial indices of multiple deprivation (Klaseen, 2000; Noble et al., 2006; Noble, Barnes, Wright, and Roberts, 2010). More recently, Finn et al., 2013; Woolard et al., 2013; Stat SA, 2014; Alkire and Santos, 2014; Ntsalaze and Ikhide, 2016; Mushongera et al., 2017; Frame et al., 2016; Rogan 2016; Pasha, 2016; OPHI, 2015; OPHI, 2017) have considered multidimensional poverty vis-a-vis gender dimension, youth dimension and cash grants at the national level using the Alkire and Foster (2011) technique and presenting mostly descriptive inferences. The Alkire and Foster MPI methodology has many advantages, which include its decompostional ability of helping to know how much each indicator and each dimension contributes to overall poverty and its ability to allow poverty comparisons across countries and regions of the world, as well as within-country comparisons between regions, ethnic groups, rural and urban areas, and other key household and community characteristics (Santos and Alkire, 2015).

Findings from empirical literatures have also found some household demographic and socioeconomic characteristics to be having influence on multidimensional poverty. The estimate of a gendered analysis carried out by Rogan (2016) showed that the incidence of multidimensional poverty is higher for female-headed households (9.4 percent) than male-headed households (6.8 percent). This indicates that female headed households are significantly more likely to be multidimensionally poor than male counterparts. A spatial analysis of MPI in the Gauteng province of South Africa by Mushongera et al. (2017) found out that low income earning households, poor accessibility to infrastructures and unemployment (as a result of low concentration of economic activities in specific locations) increases the likelihood of a household to be multidimensionally poor. Applying generalized additive model (GAM) using regression splines, Ntsalaze and Ikhide (2017) assessed the existence of critical tipping points specifically for age, government grants, education, household size and household debt service-to-income on multidimensional poverty. The study found that in household heads younger than 60 years of age, more children are associated with lower, household size of less than four and higher education attainment lowers the chances of a household to be multidimensionally poor. By applying a logistic regression, Balgi (2015), in a study carried out in Bankura district, West Bengal, found income and type of employment to be having a significant reduction effect on the chances of a household to be multidimensionally poor. In the study of Adepoju and Akinluyi (2017) where probit regression was employed, the probability of being poor was found to be decreasing in extent with increase in the level of education attained by household head. Specifically, an approximate reduction of about 1.66, 2.04 and 2.52 for household heads with primary, secondary and tertiary education was predicted respectively. Other factors found by the study to be influencing probabilities of being multidimensionally poor are household size, geopolitical location, and the gender of household head (male). For instance, being a male-headed household increased the probability of being poor by 0.15 when compared with their female counterparts. Similar findings were observed in the studies of Ele-Ojo Ataguba et al.,(2013), Mensah et al., (2014), Wu and Qi (2017), Cho, S., Kim (2017) and Maity (2018) where large family size, low level of education, employment, marital status, literacy, number of economic active member, public infrastructure were found to have significant impact on household poverty. 


\section{Data Source}

This study used information from 3033 households sampled from the Eastern Cape Province obtained during the 2014 General Household Survey. The survey is an annual household census that is usually coordinated by Statistics South Africa. Details of the sampling procedures are explained by Statistics South Africa (Stat SA, 2015). Nevertheless, to be specific, multi-stage design with probability proportionate to size was used during the survey to select primary sampling units and dwelling units. Furthermore, the 2001 population census data were used to stratify the allocated samples by geographical and population attributes at the provincial level (Stat SA, 2015). Information obtained in the GHS include demographic characteristics of households and individuals, education, health, access to public assets, ownership of private assets, household welfare, and household livelihoods among others.

\section{Analytical Techniques}

In achieving the objectives of this study, three analytical techniques were employed. Alkire and Foster family of multidimensional poverty measure and descriptive analysis (frequency distribution, percentages, charts and tables) was utilized to profile, describe and compare the multidimensional poverty status of both rural and urban households. The Tobit regression analysis was used in identifying and comparing the determinants of multidimensional poverty status between urban and rural households, respectively.

\section{Poverty Assessment: MPI}

MPI is an index of poverty which aims to quantify acute poverty, understood as a person's inability to meet simultaneously minimum internationally comparable standards in indicators related to the recently adopted Sustainable Development Goals (SDGs). It reflects deprivations in very rudimentary services and core human functioning of people; it reveals a pattern of poverty other than income poverty and expenditure poverty (Alkire and Santos, 2010).

Table 1: Multidimensional Poverty Dimensions and Indicators

\begin{tabular}{llll}
\hline Dimensions & Indicators & Deprivation Cut-Off & Weight \\
\hline Health & Mortality & $\begin{array}{l}\text { If any child under the age of 5 years has died } \\
\text { in the past 12 months/5 years. }\end{array}$ & $1 / 6$ \\
\cline { 2 - 5 } & Nutrition & $\begin{array}{l}\text { Household Dietary Diversity Score is less } \\
\text { than 4 }\end{array}$ & $1 / 6$ \\
\hline Education & Years of schooling & $\begin{array}{l}\text { Households without at least one adult having } \\
\text { at least 5 years of formal education }\end{array}$ & $1 / 6$ \\
\cline { 2 - 5 } & School attendance & $\begin{array}{l}\text { Having household children between } 7 \text { and 15 } \\
\text { not attending school }\end{array}$ & $1 / 6$ \\
\hline Standard of & Access to electricity & If there is no access to electricity & $1 / 27$ \\
\cline { 2 - 5 } & Fuel for lighting & $\begin{array}{l}\text { If household is using paraffin, candles, others } \\
\text { of nothing }\end{array}$ & $1 / 27$ \\
\hline
\end{tabular}




\begin{tabular}{llll}
\hline Dimensions & Indicators & Deprivation Cut-Off & Weight \\
\hline $\begin{array}{lll}\text { Fuel for water } \\
\text { heating }\end{array}$ & $\begin{array}{l}\text { If household is using is using paraffin, wood, } \\
\text { coal, dung, others or none. }\end{array}$ & $1 / 27$ \\
\cline { 2 - 2 } & $\begin{array}{l}\text { If household is using is using paraffin, wood, } \\
\text { coal, dung, others or none. }\end{array}$ & $1 / 27$ \\
\hline heating & $\begin{array}{l}\text { If household is using is using paraffin, wood, } \\
\text { coal, dung, other non-clean fuel. }\end{array}$ & $1 / 27$ \\
\hline Water access & If household have no access to safe water & $1 / 27$ \\
\hline Sanitation type & If not a flush toilet & $1 / 27$ \\
\hline Dwelling type & $\begin{array}{l}\text { If household live in an informal shack, } \\
\text { traditional, dwelling, caravan, tent or others. }\end{array}$ & $1 / 27$ \\
\hline Asset ownership & $\begin{array}{l}\text { If household does not own more than one of } \\
\text { radio, television, telephone or refrigerator and } \\
\text { does not own a car and does not own at least } \\
\text { one of the two assets }\end{array}$ \\
\hline
\end{tabular}

Source: Adapted from Alkire et al., (2014) and Stats SA (2014)

MPI identifies the poor using a two stage cut-off process. The stages include a sequential use of deprivation cut-off and poverty cut-off. The deprivation cut-off is within dimension cut-off while the poverty cut-off is the across dimension cut-off. A deprivation cut-off was set for each indicator and each household was then identified as deprived or non-deprived with respect to each indicator in each dimension. Weights were then applied to each dimension such that the total weights across all dimensions add up to the number of dimensions. The weighted sum of deprivations for each person was calculated and a second cut-off which cut across all the three dimensions and sets the sum of weighted dimensions in which a household must be deprived in order to be identified as multidimensionally poor was then applied. Following Alkire and Santos (2014), the cross dimensional cut-off with aggregated weight of 0.33 was adopted in identifying multidimensionally poor households. The resulting data were censored such that non-poor households have a value of 0 , while poor households have value that is continuous in nature. This study maintained the same three dimensions, but defined thirteen indicators rather than the 10 utilized in Alkire and Foster (2011), for best fit based on availability and the questions asked in the survey utilized. These dimensions and indicators are presented in Table 1. Details about MPI and can be seen in Alkire and Santos (2014). Following Santos and Alkire (2015), the weighted deprivation score $\left(Z_{i}\right)$ computation is simplified following this implicit equation:

$$
\begin{gathered}
Z_{i}=w_{i 1} E_{i 1}+w_{i 2} E_{I 2}+w_{i 1} H_{i 1}+w_{i 2} H_{i 2}+w_{i 1} S_{i 1}+w_{i 2} S_{i 2}+w_{i 3} S_{i 3}+w_{i 4} S_{i 4} \\
+w_{i 5} S_{i 5}+w_{i 6} S_{i 6}+w_{i 7} S_{i 7}+w_{i 8} S_{i 8}+w_{i 9} S_{i 9}
\end{gathered}
$$

Where $w_{i}$ is the weight relevant for each component, $E_{i}, H_{i}$ and $S_{i}$ represents the score for each component in each of the dimensions (i.e. education, health and standard of living). It takes the value of 0 or 1. 


\section{Tobit Regression}

Tobit regression model was used to determine the factors that influence multidimensional poverty among households in the Province. The Tobit regression model was considered appropriate as it takes account of the continuous but truncated nature of the dependent variable (minimum $=0$; maximum $=66.03$ ). The Akaike's Information Criterion (AIC) and the Bayesian Information Criterion (BIC) were used to compare the suitability of the Tobit model compared to the Ordinary Least Squares. Following McDonald and Moffit (1980) and Adenuga (2013), a general specification on Tobit model is specified as follows;

$$
Y_{i}= \begin{cases}y_{i}=\beta X_{i}+\varepsilon_{i} & \text { if } y_{i}^{*}>0 \\ 0=\beta X_{i}+\varepsilon_{i} & \text { if } y_{i}^{*}<0\end{cases}
$$

Where $Y_{i}$ is the dependent variable (poor) and it is continuous when household is multidimensionally poor (it equal to $y_{i}^{*}$ ), it is discrete (it equal to zero) when the household is not multidimensionally poor. The weighted MPI score for individual households was used as the regress and as a proxy for multidimensional poverty. $X$ is a vector of regressors, $\beta$ is a vector of unknown coefficients, and $\varepsilon_{i}$ is an independently distributed error term. The regressors specified as determinants of multidimensional poverty are described in Table 2. Likewise, based on the reviewed literature, the a priori expectations/ hypothesis for the regressors in the models are included in Table 2.

Table 2: Specification of Tobit Regression Variables

\begin{tabular}{|c|c|c|c|}
\hline Variables & Description & Hypothesis & Source \\
\hline \multicolumn{4}{|c|}{ Dependent Variable } \\
\hline Poor & $\begin{array}{l}\text { Recoded weighted } \\
\text { deprivation score } Z\end{array}$ & NA & \\
\hline \multicolumn{4}{|l|}{ Regressors } \\
\hline Gender & 1 if male, 0 otherwise & - & Rogan (2016) \\
\hline Age & Age of household head & - & $\begin{array}{l}\text { Adepoju and Akinluyi } \\
\text { (2017) }\end{array}$ \\
\hline Education & $\begin{array}{l}1 \text { if higher degree, } \\
0 \text { otherwise }\end{array}$ & - & $\begin{array}{l}\text { Adepoju and Akinluyi } \\
\text { (2017) }\end{array}$ \\
\hline Married & 1 if married, 0 otherwise & - & Wu and Qi (2017) \\
\hline Employment & 1 if employed, 0 otherwise & - & Mushongera et al. (2017) \\
\hline Household Size & $\begin{array}{l}\text { Number of people } \\
\text { in the household }\end{array}$ & - & $\begin{array}{l}\text { Adepoju and Akinluyi } \\
\text { (2017) }\end{array}$ \\
\hline Electricity & $\begin{array}{l}1 \text { if having access, } \\
0 \text { otherwise }\end{array}$ & - & Mensah et al. (2014) \\
\hline Agriculture & $\begin{array}{l}1 \text { if engage in agriculture, } \\
0 \text { otherwise }\end{array}$ & - & Cho and Kim, (2017) \\
\hline Total Income & & - & Mushongera et al. (2017) \\
\hline Asset Stock & Sum of asset owned & - & Mensah et al. (2014) \\
\hline
\end{tabular}

Source: Author 


\section{Result and Discussion}

\subsection{Socioeconomic Characteristics of Households}

Table 3 shows that a higher proportion of the household heads are between ages 41 and 60 years in both rural and urban areas. Going by the distribution of gender headship across geographical location, Table 3 shows that in the rural area, the majority (55.4\%) of female headed households are recorded, which is about $10 \%$ more than male headed households. Whereas in the urban area, majority $(55.3 \%)$ of male headed household are recorded. This is expected because most of the ablebodied men in the rural area have migrated to the cities for greener pastures; hence, the household is left for the women to head. Furthermore, the Table 3 which shows the distribution of respondents according to marital status of household head indicates that $42.7 \%$ of heads are living together in the urban area, while $35.6 \%$ are in the rural area. It is also surprising, as shown in Table 3, that $33.3 \%$ of the separated are located in the rural area as compared to $16.1 \%$ of same group in the urban area. The high proportion of the separated in the rural area cannot be distinguished from the observed pattern in the country, where people avoid marriages so as to avoid marital responsibilities. It needs to be mentioned that marriage is a panacea for social problems, can improve family welfare and it is imperative for society cohesion basis (Aphofung, 2012). The results of households' educational status, as shown in Table 3 , reveal that a larger proportion (43.6\%) of the household heads have education level of between grade 0 and 7 in the rural area, whereas in the rural area the majority (56.9\%) of the household heads have attained an education level between grade 8 and 12, which is secondary education, however, not all of them completed grade 12.

Table 3: Socio-economic characteristics of households

\begin{tabular}{|c|c|c|c|c|c|c|}
\hline $\begin{array}{l}\text { Socioeconomic } \\
\text { Characteristics }\end{array}$ & $\begin{array}{l}\text { Urba } \\
n=14\end{array}$ & & $\begin{array}{l}\text { Rura } \\
\mathrm{n}=15\end{array}$ & & & Pool \\
\hline Age of Head & Freq. & $\%$ & Freq. & $\%$ & Freq. & $\%$ \\
\hline $13-40$ & 441 & 30 & 385 & 24.6 & 27.2 & 826 \\
\hline $41-60$ & 649 & 44.2 & 566 & 36.2 & 40.1 & 1215 \\
\hline 61 and Above & 378 & 25.7 & 614 & 39.2 & 32.7 & 992 \\
\hline Mean & 49.7 & & 54.1 & & 60 & \\
\hline Gender & & & & & & \\
\hline Male & 812 & 55.3 & 698 & 44.6 & 49.8 & 1510 \\
\hline Female & 656 & 44.7 & 857 & 55.4 & 50.2 & 1523 \\
\hline Marital Status & & & & & & \\
\hline Living Together & 627 & 42.7 & 557 & 35.6 & 39.1 & 1184 \\
\hline Divorced & 57 & 3.9 & 26 & 1.7 & 2.7 & 83 \\
\hline Widowed & 39 & 2.7 & 66 & 4.2 & 3.5 & 105 \\
\hline Separated & 237 & 16.1 & 521 & 33.3 & 25.0 & 75.8 \\
\hline Single & 507 & 34.5 & 393 & 25.1 & 29.7 & 900 \\
\hline Educational Attainmen & & & & & & \\
\hline No Education & 83 & 5.7 & 244 & 15.6 & 327 & 10.8 \\
\hline Primary & 295 & 20.1 & 682 & 43.6 & 977 & 32.2 \\
\hline Secondary & 834 & 56.9 & 557 & 35.6 & 1391 & 45.9 \\
\hline Certificate and Diploma & 142 & 9.7 & 54 & 3.5 & 196 & 6.5 \\
\hline Higher Degree & 113 & 7.7 & 26 & 1.7 & 139 & 4.6 \\
\hline
\end{tabular}




\subsection{Pattern of Deprivation}

One of the inferences that can be made in the process of computing MPI is the pattern of deprivation among households. Figure 1 depicts the areas where deprivations are experienced among households. It is shown that urban households are mainly deprived in the fuel used for space heating and this deprivation can only be experienced in winter period. Moreover, it shows the inability of various urban households to use clean fuel (electricity) in this period of time due to the cost related to the use of various heating devices. Regarding rural area, it is seen that deprivation is experienced across all indicators of MPI, although it is more prominent with respect to space heating fuel, toilet system, dwelling, water heating fuel and cooking fuel.

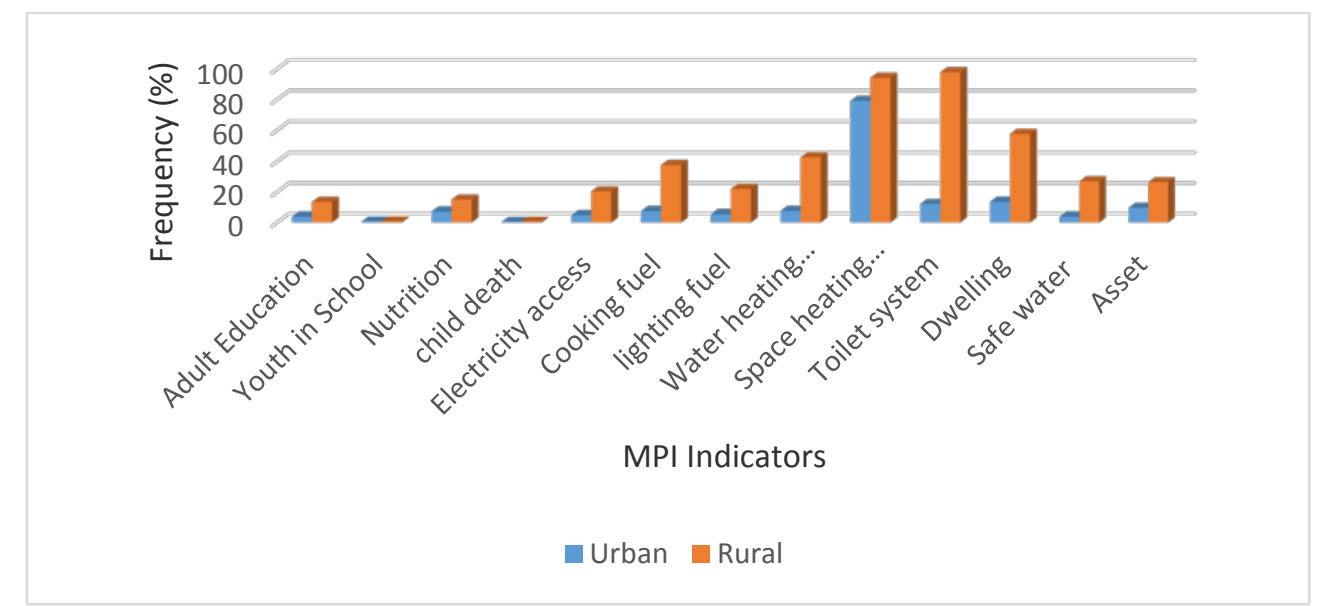

Fig. 1. Distribution of Pattern of Deprivation by Geographical Location

\subsection{Multidimensional Poverty}

Table 4: Multidimensional Poverty Index for Eastern Cape Province South Africa

\begin{tabular}{lccc}
\hline Province & $\begin{array}{c}\mathbf{H} \\
\text { (Incidence) } \\
\mathbf{k} \geq \mathbf{3 3 . 3 \%}\end{array}$ & $\begin{array}{c}\mathbf{A} \\
\text { (Intensity) }\end{array}$ & $\begin{array}{c}\text { MPI } \\
\text { (H x A) }\end{array}$ \\
\hline Urban & 0.024 & 0.428 & 0.010 \\
Rural & 0.153 & 0.439 & 0.067 \\
Total & 0.091 & 0.438 & 0.040 \\
\hline
\end{tabular}

Source: Author's Computation

From the Table 4, 2.4\% of households in the urban area are multidimensionally poor while $15.3 \%$ are multidimensionally poor in the rural area. This result does not show a severe multidimensional poverty situation in the province. The result is quite similar to the findings in the study carried out by OPHI (2017) where NIDS 2014/15 at national level was utilized. From the study, the proportion of multidimensionally poor household is $3.6 \%$ and $17.2 \%$ for both urban and rural areas, respectively. Also, the average share of deprivations of the weighted indicators poor households experience at the same time is $42.8 \%$ and $43.9 \%$ for both urban and rural household. 


\subsection{Decomposition of MPI by Dimensions and Indicators}

As earlier mentioned, one of the benefits of MPI is the ability to decompose across groups. Table 5 shows the contributions of dimensions and indicators to MPI across urban and rural areas, respectively. From the Table 5, the dimension contributing the most to household multidimensional poverty in both urban and rural locations of the Province is the standard of living dimension, but highest in the rural area. This is similar to the finding of Alkire and Santos (2010), where the standard of living was found to be the biggest contributor to multidimensional poverty in the examined MPI of 55 countries out of 104 countries. The higher contribution of the standard of living dimension to MPI in the rural area indicates that rural households lack the most in infrastructural facilities that support welfare. Also, it could be seen that the contribution of dimensions to multidimensional poverty is relatively higher in urban area with respect to education and health domains. This could be as a result of the higher number of people in the urban area who are deprived in the two dimensions than in the rural area. These findings provide insights to the priority areas for intervention in tackling multidimensional poverty in urban and rural South Africa.

Table 5. Contribution of Dimensions and Indicators to MPI at 33\% Cut-off

\begin{tabular}{lll}
\hline Indicator & Urban & Rural \\
\hline Dimension 1: Education & $\mathbf{0 . 2 8 9}$ & $\mathbf{0 . 2 2 2}$ \\
Adult Education & 0.256 & 0.210 \\
Youth in School & 0.033 & 0.011 \\
Dimension 2: Health & $\mathbf{0 . 2 5 6}$ & $\mathbf{0 . 1 9 6}$ \\
Nutrition & 0.245 & 0.188 \\
Child Death & 0.011 & 0.008 \\
Dimension 3: Standard of Living & $\mathbf{0 . 4 5 5}$ & $\mathbf{0 . 5 8 3}$ \\
Electricity & 0.052 & 0.050 \\
Cooking Fuel & 0.064 & 0.073 \\
Lighting Fuel & 0.059 & 0.052 \\
Water Heating Fuel & 0.064 & 0.071 \\
Space Heating Fuel & 0.087 & 0.083 \\
Toilet System & 0.030 & 0.084 \\
Dwelling & 0.035 & 0.070 \\
Safe water access & 0.005 & 0.039 \\
Asset & 0.059 & 0.060 \\
\hline
\end{tabular}

Source: Author's Computation from GHS 2014

\subsection{Tobit Regression Estimate on Determinants of Multidimensional Poverty}

The AIC and BIC statistics for the Tobit regression is 2865.242 and 2929.494 respectively, whereas that of OLS is 12679.04 and 12737.94 , respectively. Tobit regression is considered suitable because of the lower values of AIC and BIC, respectively. The result of the Tobit regression result is presented in Table 6. In the modelling, the existence of multicollinearity among the variables was initially investigated. The choice to include a variable was made by examining the variance inflation factor (VIF) statistics. Any variable with VIF of 10 or more is removed from 
the model. The VIF statistics of variables in the regression are presented in the Table 6 . While the average variance inflation factor (VIF) for the model was 1.54, none of the variables have a VIF greater than 10 . This suggests the non-existence of multicollinearity problem in the model. Table 6 further revealed that factors that determine poverty among rural households are gender of head, education attainment and employment status of head, access to electricity, household engagement in agriculture, household monthly income and asset stock; whereas in urban households' multidimensional poverty determinants are only education attainment of head, household access to electricity and asset stock.

The coefficient of gender is statistically significant $(p<0.05)$ and positive for rural households only. This implies that if all other factors are held constant, rural household headed by men have about $10.7 \%$ chances of becoming multidimensionaly poor. This is contrary to the notion that due to the continued presence of discrimination against women in the labour market, lower education, lower salaries (Anyanwu, 2014) and the poor access to assets and resources by women, men are likely not to fall into poverty when compared to their female counterpart. A reason for this is because the majority of households in the rural areas are headed by women, and since women are considered vulnerable in the society they have better access to government support than men, this could aid their household welfare, thereby making them less open to poverty. Moreover, having a male as the head who has control over resources of the household, the finding suggests that the utilization of resources by these male headed households does not have any significant impact on the welfare of household members.

Table 6. Tobit Regression estimates for Determinants of Multidimensional Poverty

\begin{tabular}{|c|c|c|c|c|c|}
\hline \multirow[t]{2}{*}{ Variables } & \multicolumn{2}{|c|}{ Urban } & \multicolumn{2}{|c|}{ Rural } & \multirow[t]{2}{*}{ VIF } \\
\hline & Coefficient & P-Value & Coefficient & P-Value & \\
\hline Constant & -7.2067 & 0.825 & 14.3909 & 0.342 & \\
\hline Gender & 3.1674 & 0.802 & 10.7123 & $0.042^{\star \star}$ & 1.42 \\
\hline Age & -0.2729 & 0.568 & -0.0714 & 0.662 & 1.56 \\
\hline Marital Status & 4.4508 & 0.753 & -5.5617 & 0.335 & 1.46 \\
\hline Education & -45.6668 & $0.000^{*}$ & -32.521 & $0.000^{*}$ & 1.74 \\
\hline Employment & -2.9269 & 0.669 & -4.07558 & 0.159 & 1.48 \\
\hline Access to electricity & 20.0423 & $0.004^{*}$ & 16.7229 & $0.000 *$ & 1.22 \\
\hline Agriculture & -326.0059 & - & -9.1406 & $0.075^{\star \star \star}$ & 1.22 \\
\hline Monthly Income & -0.0009 & 0.775 & -0.0029 & $0.039 * *$ & 2.02 \\
\hline Household Size & 2.4940 & 0.290 & -0.0898 & 0.922 & 1.00 \\
\hline Asset stock & -19.2861 & $0.000^{*}$ & -19.3081 & $0.000^{*}$ & 2.25 \\
\hline Sigma & 55.4398 & - & 53.06776 & - & \\
\hline Number of obs. & 1467 & & 1563 & & \\
\hline LR chi² & 170.01 & & 411.25 & & \\
\hline Prob > chi2 & 0.0000 & & 0.0000 & & \\
\hline Log likelihood & -244.0731 & & -1420.6208 & & \\
\hline Pseudo $\mathrm{R}^{2}$ & 0.2583 & & 0.1264 & & \\
\hline
\end{tabular}

${ }^{*}, * *$, and ${ }^{* * *}$ denote significance of estimated coefficients at $1,5,10 \%$ levels of significance respectively. 
The coefficient of education variable is statistically significant $(p<0.01)$ and negative to both urban and rural households. This is consistent with the expectation of this study and the findings of Adepoju and Akinluyi (2017), Oyekale et al., (2012), Anyanwu (2014) and Twerefou et al. (2014). The result indicates that households in both urban and rural areas having a head that is more educated are less likely to become multidimensionally poor. Education is an enabler; it empowers a head with skills and requirements for employment opportunities and earning a living. Specifically, education is linked to labour force participation and its relationship to poverty could be established through the labour market, labour productivity and wages (Oyekale, et al., 2012; Anyawu, 2013). Moreover, a low level of the household head's education could hinder the ability to accumulate wealth and could lead to a vicious cycle of multidimensional poverty, which can affect the head's generation. The result of this study also indicates that having access to electricity increases the chances of becoming multidimensionally poor in both urban and rural areas. This is inferred from the coefficient of access to electricity that is statistically significant $(p<0.05)$ and positive. Though this is contrary to the a priori expectation of this study, it could however be as a result of the cost attached to the usage of electricity. As a component of household expenditure, electricity consumption cost could increase or decrease household expenditure, or limit the benefit of electricity access. For instance, in order to minimize cost of usage, households would be unable to use electrical gadget that consumes more, especially for space heating and water heating and most likely discourage the long period of home cooking; households would thus resort to the use of unclean fuel or stay without warmth, which could household members health. This is similar to the finding of Gounder (2012) carried out in Geutamela, where access to electricity by household was found to lower per capita consumption of households. High electricity price and subsequent high consumption cost impact consumption on other necessary goods and services.

Furthermore, engagement in agricultural activities significantly reduces the probability of being multidimensionally poor, though the expectation is consistent for rural households only. This is inferred from the coefficient of agriculture that is negative and significant at $p<0.10$. The coefficient implies that all the other factors which held constant engagement in agricultural activities reduce the probability of being multidimensionally poor by about $9.14 \%$. This emphasizes hypothetical arguments and empirical evidences that agriculture can be used as a tool for reducing rural poverty. This is so because, unlike the urban households, most of the rural dwellers engage in agriculture and they depend on it as a key source of their livelihood (Cervantes-Godoy and Dewbre 2010; World Bank, 2008). Among the variables that were investigated, household monthly income parameter is negative and statistically significant $(p<0.05)$ for rural household only. This implies that, if other variables are held constant, the probabilities of becoming poor are reduced as household income increases in the rural area of the province. The magnitude of effect is, however, minute, meaning that the rural household income is quite minute to allow household achieve desired welfare.

In addition, the coefficient of asset ownership of household is with a negative sign and significant $(p<0.05)$ for both urban and rural households, as expected. This implies that, if other variables are held constant, the more assets a household owns the less likely they are to be multi-dimensionally poor. This is because asset ownership is both of economic advantage and a source of social prestige. 
Accumulated assets could be sold or used as credit collateral in times of crises, shortages or distress; it could also be used to get extra income through service provision or rentage. Simply put, asset is a store of wealth. Carter and Barret (2006) mentioned that insufficient access to assets jeopardises the long-term ability of households to pull themselves out of poverty. Carner, 1998, Ellis, 2000 and DIFID, 2000 explained the indispensable role of household asset in household livelihood and welfare in their sustainable livelihood framework analysis. Accordingly Anderson (2012) buttressed that asset endowments provide a cushion against income shocks, are a source of future income and consumption streams and are generally indicative of future economic wellbeing of households.

\section{Conclusion}

This paper empirically assessed multidimensional poverty status and it also identified the determinants of households' multidimensional poverty in the Eastern Cape Province of South Africa. The descriptive statistics result revealed that though the multidimensional poverty is low in both geographical locations of the province, the intensity of multidimensional poverty is however high. The study further shows that the standard of living dimension is the highest contributor to multidimensional poverty in both urban and rural areas, but it is highest in the rural area. It is, however, surprising to observe that the respective contribution of education and health dimensions to multidimensional poverty is higher in the urban area than the rural area. The Tobit regression result indicates three similar poverty influencing factors (education attainment of household head, access to electricity and asset stock) in both geographical locations. The study clearly revealed the need for intensification of rural development programmes by the Provincial government. These programmes should also focus on addressing the standard of living indicators like providing access to clean fuels, affordable and improved dwelling and toilet system. Enacting policies that promote education for all, aid asset accumulation for the poor and expansion of electricity subsidies coverage, especially during winter period, could facilitate reduction of multidimensional poverty in the Province. Additionally, since reducing poverty through agriculture can be achieved in the rural area only, continual government transfers to rural households could be conditioned to household engagement in agricultural activities and this could facilitate household engagement in agricultural activities. This paper contributes to deeper understanding of poverty dynamics at the subnational level in South Africa by using Eastern Cape Province as a case study, a province that is known for a long standing and prevalent poverty incidence. Given that the standard of living dimension contributes more to multidimensional poverty and are connected to services provided by the Provincial government, this study thus argued that an incorporated approach to service delivery is key to reducing multidimensional poverty in Eastern Cape Province. This as well will eliminate social services related protests in the Province. Aside, following the submission of the World Bank (2016) that the global poor in developing countries are predominantly rural, young, poorly educated, mostly employed in the agricultural sector, and live in larger households with more children, the contribution of this study is in its advocacy for policies that could stimulate the improvement in significant factors (education, electricity access, asset accumulation and rural development) 
that have influence on multidimensional poverty, both in the rural and urban sector. The poorly educated today could have been caused by poor education opportunities or poorly educated parents, and could also lead to poor education of offsprings in future; hence, leading to a generational transmission of poverty. Considering the importance of education as established in this study, developing regions outside Africa that have a higher incidence of poverty should enact policies that limit the minimum education level a child or individual must attain. This level must have been proven to be a threshold that could reduce the tendency of poverty. Aside education, access to electricity which is also a bane in developing countries, especially South Asia, stands out as a very significant factor in this study. Expanding access to electricity by providing access to off-grid non-renewable energy sources (solar) and provision of subsidy in order to own solar panels through public-private partnership and increasing the capacity of solar panels beyond lighting alone have a positive impact in the fight against poverty in the long-run in developing countries outside Africa. Also, the study significantly identifies the role of asset accumulation for multidimensional poverty reduction, which is equally important for other regions with high incidence of poverty. The study here emphasizes that sustainable public-private partnership programmes and projects could be implemented in order to assist the poor utilize various resources at their disposal for self-sufficiency and income generation, which is indispensable for asset accumulation. An approach that combines partial support from government or private agencies and any available resources from the poor to ensure the commitment of the poor could be adopted in this regard in these regions. The application of Alkire and Foster multidimensional poverty measure by researchers, development partners and governments will in no doubt aid in the global pursuit of reducing extreme poverty in all its' dimensions by the year 2030.

\section{References}

Abdul-Mamin A., Shamshiry E. (2014) Linking sustainable livelihoods to natural resources and governance: the scale of poverty in the muslim world, Springer.

Adenuga A., Omotesho O., Ojehomon V., Diagne A., Olorunsanya E. Adenuga O. (2013) Poverty analysis of rice farming households: a multidimensional approach, Albanian Journal of Agricultural Sciences, 12(4): 641-651.

Alem Y., Köhlin G., Stage J. (2014) The persistence of subjective poverty in urban Ethiopia, World Development, 56, 51-61.

Alkire S., Foster J., (2011) Counting and multidimensional poverty measurement. Journal of Public Economics, 95(7): 476-487.

Alkire S., Foster J., Seth S., Santos M., Roche J., Ballon P. (2015): Multidimensional poverty measurement and analysis, Oxford University Press, USA.

Alkire S., Santos M. (2010) Acute multidimensional poverty: a new index for developing countries, Oxford Poverty and Human Development Initiative Working Paper 38, University of Oxford.

Alkire S., Santos M. (2014) Measuring acute poverty in the developing world: Robustness and scope of the multidimensional poverty index, World Development, 59, 251-274. 
Anderson B. (2012) Converting asset holdings into livelihood: An empirical study on the role of household agency in South Africa, World Development, 40(7): 1394-1406.

Anyanwu J. (2014) Marital status, household size and poverty in Nigeria: Evidence from the 2009/2010 survey data, African Development Review 26(1): 118-137.

Baiyegunhi L. J. S. (2014) Social capital effects on rural household poverty in Msinga, KwaZulu-Natal, South Africa, Agrekon, 53(2): 47-64.

Baiyegunhi L. J. S. (2014): Rural households' social capital and welfare: a case study of Msinga, KwaZulu-Natal, South Africa, Journal of Agriculture and Rural Development in the Tropics and Subtropics (JARTS): 114(2): 123-132.

Baiyegunhi L., Fraser G. (2014) Poverty incidence among smallholder farmers in the Amathole District Municipality, South African, Journal of Human Ecology 46(3): 261-273.

Bhorat H., Van der Westhuizen, C. Jacobs T. (2009) Income and non-income Inequality in post-apartheid South Africa: what are the drivers and possible policy interventions?, Development Policy Research Unit Working Paper 09/138, University of Cape Town.

Biyase M., Zwane T. (2018). An empirical analysis of the determinants of poverty and household welfare in South Africa, The Journal of Developing Areas, 52(1): 115130.

Carney D. (1998) Implementing the Sustainable Rural Livelihoods Approach Paper presented at DFID Natural Resource Advisers Conference.

Carter M.R., Barrett C.B. (2006) The economics of poverty traps and persistent poverty: An asset-based approach, The Journal of Development Studies, 42(2): 178-199.

Cervantes-Godoy D., Dewbre J. (2010) Economic Importance of Agriculture for Poverty Reduction, OECD Food, Agriculture and Fisheries Working Papers 23.

Chamhuri S., Hossain M., Murad M. (2004) The nature and extent of poverty and its reduction strategies: A comparative study of the experiences from some AsianMuslim countries. In Proceedings of international conference on poverty in the Muslim world and communities: Causes and solutions, 1-13.

Cho, S., Kim, T. (2017) Determinants of poverty status in Rwanda, African Development Review, 29(2): 337-349.

DFID (2000) Sustainable Livelihoods Guidance Sheets. Department for International Development (DFID): London, UK.

Dunga S. H. (2017) A gender and marital status analysis of household income in a low-Income township, Studia Universitatis Babes-Bolyai Oeconomica, 62(1): 2030.

Ele-Ojo Ataguba, J., Eme Ichoku, H., Fonta, W. M. (2013) Multidimensional poverty assessment: applying the capability approach. International Journal of Social Economics, 40(4): 331-354.

Ellis F. (2000) Rural livelihoods and diversity in developing countries. Oxford University press.

Finn A., Leibbrandt M., Woolard I. (2013) What happened to multidimensional poverty in South Africa between 1993 and 2010? A Southern Africa Labour and Development Research Unit Working Paper 99, University of Cape Town.

Frame E., De Lannoy, A., Leibbrandt M., 2016. Measuring multidimensional poverty among youth in South Africa at the sub-national level.

Gibson J. (2016) Poverty measurement: we know less than policy makers realize, Asia and the Pacific Policy Studies, 3(3): 430-442. 
Gounder N. (2012) The determinants of household consumption and poverty in Fiji, Discussion Papers Economics, Griffith University.

Jansen A., Moses M., Mujuta S., Yu D. (2015) Measurements and determinants of multifaceted poverty in South Africa, Development Southern Africa, 32(2): 151169.

Kingdon G.G., Knight J. (2006) Subjective well-being poverty vs. income poverty and capabilities poverty?, The Journal of Development Studies, 42(7): 1199-1224.

Klasen S. (2000) Measuring poverty and deprivation in South Africa, Review of Income and Wealth, 46(1): 33-58.

Lipton M., Ravallion M. (1995) Poverty and policy. Handbook of development economics, 3: 2551-2657.

Maity, S. (2018) Multidimensional poverty status of Bodo tribes of Udalguri District, Bodoland, Assam. Journal of Economic Development, 43(1): 29-47.

Maloma I. (2016) The socioeconomic determinants of household poverty status in a low-income settlement in South Africa. International Journal of Social Sciences and Humanity Studies, 8(2): 122-131.

McDonald J.F., Moffitt R.A. (1980) The uses of Tobit analysis, The Review of Economics and Statistics, 318-321.

Mensah, E. J., Huchet-Bourdon, M., Latruffe L. (2014). Infrastructure access and household welfare in rural Ghana. African Development Review, 26(3): 508-519.

Meth C., Dias R. (2004) Increases in poverty in South Africa, 1999-2002. Development Southern Africa, 21(1): 59-85.

Meyer B.D., Sullivan J.X. (2003) Measuring the wellbeing of the poor using income and consumption, Journal of Human Resources, 38(5): 1180- 1220.

Meyer D. F., Nishimwe-Niyimbanira R. (2016) The impact of household size on poverty: an analysis of various low-income townships in the Northern Free State region, South Africa, Etude de la Population Africaine, 30(2).

Mushongera D., Zikhali P., Ngwenya P. (2017) A multidimensional poverty index for Gauteng Province South Africa: Evidence from Quality of Life Survey Data, Social Indicators Research, 130(1): 277-303.

Noble M., Barnes H., Wright G., Roberts B. (2010) Small area indices of multiple deprivation in South Africa, Social Indicators Research, 95(2): 281-297.

Noble, M., Babita, M., Barnes, H., Dibben, C., Magasela, W., Noble, S., et al. (2006). The provincial indices of multiple deprivation for South Africa 2001. Oxford: University of Oxford.

Ntsalaze L., Ikhide S. (2016) Rethinking Dimensions: The South African Multidimensional Poverty Index, Social Indicators Research, 1-19.

Oxford Poverty and Human Development Initiative (2017) South Africa Country Briefing, Multidimensional Poverty Index Data Bank. OPHI, University of Oxford. Available at: http://www.ophi.org.uk/multidimensional-poverty-index/mpi-country-briefings/

Oxford poverty and human development initiative. (2015) Global multidimensional poverty index (MPI) at a glance-OPHI country briefing June 2015: South Africa. Oxford: Department of International Development.

Oyekale A., Adepoju A., Balogun A. (2012) Determinants of poverty among riverine rural households in Ogun State Nigeria, Studies in Tribes Tribunals, 10(2): 99105. 
Pasha A. (2016) Impact of cash grants on multidimensional poverty in South Africa, Courant Research Centre: Poverty, Equity and Growth - Discussion Papers, No. 208.

Posel D., Rogan M. (2014) Measured as poor versus feeling poor: comparing money-metric and subjective poverty rates in South Africa, Journal of Human Development and Capabilities, 1-19.

Rogan M. (2016) Gender and multidimensional poverty in South Africa: Applying the global multidimensional poverty index (MPI): Social Indicators Research, 126(3): 987-1006.

Santos M.E. and Alkire S. (2015) Training material for producing national human development reports. MPI: Construction and analysis. Oxford: Oxford Poverty and Human Development Initiative. http://hdr.undp.org/sites/default/files/mpi_ trainingmaterial_mcc_mk_clean_june_2015.pdf.

Seekings J. (2007) Poverty and inequality after apartheid. CSSR Working Paper No. 200, Centre for Social Science Research, University of Cape Town.

Sekhampu T. J. (2013) Determinants of poverty in a South African Township. Journal of Social Sciences, 34(2): 145-153.

Statistics South Africa (2014) The South African MPI: Creating a multidimensional poverty index using Census data / Statistics South Africa. Pretoria, 0001.

Statistics South Africa (2015) General Household Survey 2014. Statistics South Africa. Published by Statistics South Africa, Pretoria, 0001.

Twerefou D. K., Senadza B., Owusu-Afriyie (2014) Determinants of poverty among male-headed and female-headed households in Ghana, Ghanaian Journal of Economics, 2, 77-96.

Woolard I.D., Finn A., Klasen S. (2013) MPI versus Income Poverty in South Africa using the South National Income Dynamics Study.

World Bank (2008): "World Development Report: Agriculture for Development", United States by Quebecor World, USA.

World Bank 1990. World Development Report 1990: Poverty. New York: Oxford University Press.

World Bank 2001. World Development Report 2000-2001: Attacking Poverty. El Banco.

Wu, Y., Qi, D. (2017) A gender-based analysis of multidimensional poverty in China. Asian Journal of Women's Studies, 23(1): 66-88.

Wurku S., Marangu J. (2015) The Impact of Remittance on Poverty: Evidence from the South African National Income Dynamics Study (NIDS): African Human Mobility Review (AHMR),1(1): 1-14. 